\title{
Orman suçlarında tazminat ve ağaçlandırma bedeli hesabı
}

\section{Compensation and afforestation costs in forest crimes}

\author{
Hüseyin $A Y A Z^{1}$, Sevim INANÇ ${ }^{2}$ \\ ${ }^{1}$ Trabzon Üniversitesi Hukuk Fakültesi Kamu Hukuku Bölümü Trabzon, Türkiye \\ ${ }^{2}$ Artvin Çoruh Üniversitesi Orman Fakültesi Orman Mühendisliği Bölümü Artvin, Türkiye
}

\section{Eser Bilgisi / Article Info}

Araştırma makalesi / Research article

DOI: $10.17474 /$ artvinofd.408786

Sorumlu yazar / Corresponding author Hüseyin AYAZ

e-mail: hayaz@ktu.edu.tr

ORCID: 0000-0002-3930-3207

Geliş tarihi / Received

22.03.2018

Düzeltme tarihi / Received in revised form

30.10.2018

Elektronik erişim / Online available

18.11.2018

Anahtar kelimeler:

Orman koruma

Orman suçu

Orman örtüsü tahribi

Keywords:

Forest protection

Forest crime

Forest destruction

\section{Özet}

Devlet ormanlarına yasa dışı müdahalede bulunarak zarara sebep olanların, talep halinde bu zararı karşılamaları yasal zorunluluktur. Yasa dışı faaliyet sonucu sebep olunan zararın tam olarak karşılanması ve sebepsiz zenginleşmeye de yol açılmaması gerekir. Suç nedeni ile zarara uğrayan orman idaresi, sanıkların gönüllü olarak zararı karşılamalarını talep etmekte, aksi halde yargı yoluna başvurmaktadır. Sebep olunan zarar için tazminat ve açılan orman alanı için de ağaçlandırma bedeli orman kanununun ilgili hükümlerine göre hesaplanmaktadır. Konunun yargıya intikali sonrasında ise mahkemeler tarafından bu talebin yasalara uygunluğu araştırılmakta, bunun için de orman mühendisi bilirkişilere başvurulmaktadır. İdare talebi ve bilirkişiler tarafından hesaplanan bedeller arasında uyumsuzluklar ortaya çıkabilmektedir. Suç nevilerine göre, tazminat ve ağaçlandırma bedeli ödenmesinin gerekip gerekmediği ve miktarı konularında tereddütler yaşanmaktadır. Bu çalışmada, öncelikle orman suçları için karşılanması gerekli zarar ve ağaçlandırma bedeli hesaplamalarıyla ilgili mevzuat ele alınmış ve örnek Yargıtay kararlarına da dayanılarak açıklanmıştır. Daha sonra ise mevzuatın ön gördüğü yaptırımların oluşan zararın ve ağaçlandırma bedelinin tespitindeki yeterliliği, hakkaniyete uygunluğu konusunda da değerlendirmeler yapılmış öneriler geliştirilmiştir. Yapılan inceleme ve değerlendirmeler sonucunda, tazminat hesaplarının çoğunlukla odun hammaddesi zararına yönelik olduğu, biyolojik çeşitlilik ve ekosistemin olumsuz etkilenmelerinin hesaba katılmadığı, devlet ormanlarından ağaç kesme suçlarındaki tazminat hesaplamasının yetersiz kaldığı, ağaçlandırma bedel hesaplarında hatalar yapıldığı görülmüştür. Orman fonksiyonlarının daha somut biçimde açıklanmakta olduğu günümüzde, orman tahriplerinde zarar hesaplamalarının yeniden ele alınması gerekli görülmektedir.

\begin{abstract}
It is a legal obligation that those who commit crimes against the state forests compensate for the damage they cause upon the request of the state organization. The damage caused by illegal activities should be fully compensated, however this should not lead to unjust enrichment. The forest administration, which has suffered damages due to crime, demands that the defendants voluntarily compensate for the damage, otherwise the case is taken to court for resolution. The compensation for the damage caused and the reforestation cost for the damaged forest area are calculated according to the relevant provisions of the forest law. After the case has been filed, the court investigates its legal and regulatory compliance and consults forest engineer experts. There may be discrepancies between the demand of the administration and the prices calculated by the experts. According to the offenses, there are doubts about whether the amount of the compensation and afforestation costs comply with the regulations, and whether the compensation and afforestation costs should be paid at all. In this study, first of all, the legislation related to damages and reforestation cost calculations for the forest crimes are discussed and explained based on the decisions of the Supreme Court. Afterwards, the recommendations were made about the adequacy of the compensation and the cost of afforestation envisaged by the legislation and the compliance with the equity. As a result of the examinations and evaluations, it is observed that compensation calculations are mostly directed towards the loss of wood raw materials, negative effects of biodiversity and ecosystem are not taken into account, calculation of compensation for illegal cuttings in state forests is insufficient and cost calculations for afforestation is erroneous. Today, forest functions are explained more comprehensively. Therefore, it is necessary to reconsider the calculations of the cost of compensation for the damage in forest areas.
\end{abstract}

\section{GiRiş}

Orman tahribi küresel anlamda en önemli sorunlardan birisidir. İnsanoğlu, Dünyada ve özellikle de gelişmekte olan ülkelerde ormana saldırmakta, tarla açmak, yapacak ürün ve yakacak odun sağlamak gibi amaçlarla sürekli olarak ormanları tahrip etmektedir. Sonuç olarak da Dünya kara yüzeyinin yaklaşık \%31'ini kaplayan ormanlar 
gün geçtikçe azalmaktadır. Dünya üzerindeki orman tahribatı tedricen azalmakla birlikte, FAO verilerine göre 2000-2010 yılları arasında toplam 13 milyon hektar orman yok edilmiştir (URL-1 2018).

Türkiye'de arazi kullanımında bilimsel ilkelerin hemen hiç dikkate alınmadığı, ekolojik ve ekonomik kullanımı konusunda da yasal bir düzenin olmadığı eleştirisi yapılmaktadır (Gümüş 2004). Bu rastgele kullanım 1990'ı yılların ortalarına kadar orman azalmasına sebep olmuştur. Bu yıllardan itibaren, OGM (Orman Genel Müdürlüğü) envanterlerine göre, azalmanın yavaşladığı, durduğu hatta son yıllarda da orman varlığında alan ve servet olarak artışlar yaşandığı ifade edilmektedir. Nitekim 1973 yılında Türkiye'nin orman alanı yaklaşık 20,2 milyon hektar iken 2015 yılı itibari ile 22,3 milyon hektara ulaştığı tespit edilmiştir (URL-2 2018). Orman tahribatındaki azalmanın en önemli sebebi, kırsal nüfusun kentlere göçmesi olarak değerlendirilebilir. Bununla birlikte, ülkemizde de ormanlara yönelik plansız ve yasal olmayan yararlanmalar da sürmektedir. Orman suçlarının önemli bir kısmı gizli kalmasına rağmen tespit edilmiş orman suçu sayısı halen 10000 adet/yıl seviyesindedir. Öte yandan yine OGM tahminlerine göre, 2010-2015 yılları arasında devlet ormanlarından ortalama 4,51 milyon ster odun yasa dışı yollarla üretilmiştir (OGM 2016). Sonuçta orman suçları ve tahrip edilen ormanlık alanlar Türkiye için halen de önemli bir ormancllık sorunudur.

Türkiye'de ormanlar ülkenin yaşanılabilirliği için vazgeçilmez unsur olarak görülmüş (Diker 1947) ve 1961 yılından anayasal güvenceye kavuşturulmuştur (Aksoy 1987). Kabul edilmiş orman yasalarında da ormanların korunmasını ve sürekliliğinin sağlanmasını öngören kurallar konulmuştur. Yine, orman suçlarının tarifi ve bu suçları işleyenler için uygulanacak cezai yaptırımlar tespit edilmiştir. Orman suçu nedeni ile sebep olunan zararın nasıl hesaplanacağı konusu da kanun ve yönetmeliklerle açıklanmıştır.

Bu çalışmada, orman suçları nedeniyle oluşan zararın ve ağaçlandırma bedelinin hesaplanması konusu ele alınmıştır. Süreç içindeki yasa değişiklikleri de dikkate alınarak, gerekli görülen yerlerde Yargıtay kararlarına da atıfta bulunularak, yürürlükteki mevzuata göre, zarar hesaplarının nasıl yapılması gerektiği açıklanmıştır. Ayrıca, suçlar nedeniyle oluşan zararın ile ağaçlandırma bedeli hesaplanmasındaki mevzuatın hakkaniyete uygunluğu konusunda da değerlendirmeler yapılmış, gerek zarar tespit yöntemi ve gerekse de ekosistemin uğradığı zararın tespiti için önerilerde bulunulmuştur.

\section{MATERYAL VE YÖNTEM}

Araştırmada materyal olarak, Osmanlı İmparatorluğu'nun son dönemlerinden itibaren orman suçları konusundaki yasal düzenleme ve değişiklik metinleri kullanılmıştır. Yine, kanunların uygulanışını gösterir, yönetmelik, tamim vb. metinler de temin edilmiştir. Ayrıca, farklı kanunların yürürlükte olduğu dönemlerdeki üst yargı mercileri tarafından verilmiş kararlar derlenmiştir. Elde edilen bu veriler, tarihi akışta dikkate alınarak irdelenmiş, değerlendirilmiştir. Çalışmada, kanunlar ile yargı kararlarının uyumu, tazminat ve ağaçlandırma bedeli hesaplamalarının hakkaniyeti sorgulanmış, değerlendirilmiş, öneriler geliştirilmiştir.

\section{BULGULAR}

\section{Tarihi Süreçte Orman Suçlarına Yönelik Tazminat ve} Ağaçlandırma Bedeli

Osmanlı İmparatorluğunun son dönemlerine kadar cibal-i mubaha (hiç kimsenin mülkiyetinde olmayan dağlar) (URL-3 2018) olarak görülen ve herkesin serbestçe yararlanmasına açık olan ormanlar 1800'lü yılların ortalarından itibaren devlet kontrolüne alınmaya çalışılmıştır. Bu kapsamda, devlete ait ormanlardan izinsiz yararlanmalar yasaklanmaya ve yasağı ihlal edenler için de yaptırımlar uygulanmaya başlanmıştır. Yaptırımlardan birisi de suç nedeni ile oluşan idare zararının ödettirilmesidir.

Tazminat, hukuka aykırı bir eylem sonucunda meydana gelen maddi veya manevi zarara karşlık olarak ödenmesi gerekli bedeldir. Haksız fiilden söz edebilmek için; a) fiil, b) hukuka aykırıık, d) zarar, e) zararla fiil arasında bir bağ olmalıdır. Tazminata karar verebilmek için, önce zarar miktarının hesaplanması gerekir. Zararı ispat etmek tazminat isteyene düşer. Zarar, haksız fiilin işlendiği gündeki değeri göz önüne alınarak hesaplanır. 
Orman suçları nedeniyle ödenmesi gerekli tazminatlar konusundaki ilk düzenlemeler 1870 tarihli Orman Nizamnamesinde (kanununda) bulunmaktadır (Gülen ve Özdönmez 1981). Kanunun 38 'inci ve 43 . maddelerinde; “...hilafı memnuiyetten dolayı zarar ve ziyan tebellür eyler ise tazmin ettirilir" (yasağa aykırılık nedeniyle zararın meydana gelmesi durumunda ödettirilir) denilmektedir (Bingöl 1990). Bahse konu kanunda, tahrip olunan orman alanları için ağaçlandırma bedeli ödenmesi hususunda ise her hangi bir hüküm bulunmamaktadır.

Türkiye Cumhuriyetinin kuruluşu sonrasında kapsamlı düzenlemeler içeren ilk orman kanunu 1937 tarih ve 3116 sayılıdır. Kanunun 105 'inci maddesinde, devlet ormanlarındaki ağaçların hayatiyetine son verilmesi ve orman içindeki diğer diri örtünün tahribi yasaklanmış olup bu suçların işlenmesi halinde uygulanacak cezaların yanı sıra, orman idaresinin isteğine bağlı olarak, tazminat da ödenmesi ön görülmüştür. Ödenecek tazminat, mıntıkalara göre tespit edilmiş "tarife bedeli" (orman ürününün kütügü dibinde dikili haldeki kıymeti) üzerinden hesaplanacaktır. Kanunun 108, 109 ve 110'uncu maddelerinde ise devlet ormanlarında izinsiz maden ve taş ocağı açılması, bina yapılmasının yasak olduğu belirtilerek bu eylemler için ceza uygulamasının yanı sıra sebep olunan zararın da ilgililerce karşılanması zorunlu kılınmıştır. 3116 sayılı kanunda suç nedeni ile oluşan zararın hesaplanması konusu açıklanmamış olmakla birlikte, uygulanmasını gösteren Nizamnamenin 22. Maddesine göre tazminatın "tarife bedeli" üzerinden hesaplanacağı belirtilmiştir (Kayganacıoğlu vd 1976).

Yürürlüğe konulan 1956 tarih ve 6831 sayılı orman kanununda, borçlar kanunundaki genel hükümlerden farklılıklar içeren tazminatlara yer verilmiştir. Nitekim kanunun 35 ve 98'inci maddeleri gereği, orman içindeki veya orman sınırlarına $10 \mathrm{~km}$. mesafedeki köylülere, ormana bitişik kasaba halkına, felaketzedelere ve iskâna tabii tutulacak halka veya bu yerler tüzel kişiliklerine bedelsiz ya da düşük bedelle verilen orman emvalinin her hangi bir şekilde satılması ya da elden çıkarılması halinde, ürünün rayiç değerinin (98'inci maddede tam tarifesinin) iki katı miktarında tazminata hükmedilmekteydi. Ancak bu düzenleme 2008 tarih ve 5728 sayılı kanun ile kaldırılmıştır. Yine, kanunun 113'üncü maddesine göre, dikiliden ağaç kesilmesi halinde, her hangi bir değer kaybı veya ürünün zapt edilip edilmediğine bakılmaksızın "mahalli rayiç" esas alınarak tazminat ödenmesi gerekmektedir.

Dikiliden ağaç kesme dışındaki suçlarda, 6831 sayılı orman kanununun 112'inci maddesi ilk metni (orijinal metin); "Bu kanunda yasak edilen fiilin ikaı (yapılması) yüzünden husule gelen zarar için talep halinde ayrıca tazminata hükmolunur." denilmektedir. Burada tazminatın nası hesaplanacağı yönünde bir açıklama bulunmamaktadır. Uygulamada, suç nedeni ile oluşan zarar 1968 yılına kadar çoğunlukla "tarife bedeli" üzerinden hesaplanmıştır. Sebep olarak, 3116 sayılı orman kanununun uygulamasını gösteren Orman Nizamnamesinde belirtilen "tarife bedelinin” dikkate alındığı söylenebilir. Ancak, 11.03.1968 gün ve 967/154 sayılı Yargıtay İçtihadı Birleştirme Büyük Genel Kurulu Kararı gereğince, dikiliden ağaç kesme suçları dışındaki orman suçlarında tazminat Borçlar Kanunu genel hükümlerine göre tespit edilecektir. Bu değer, haksız fiil nedeniyle uğranılan zarar (gerçek zarar) olarak ifade edilmektedir. Nitekim orman kanununun 12 'inci maddesinde de 1983 tarih ve 2896 sayılı kanunla değişiklik yapılmış ve tazminatın "gerçek zarar" üzerinden hesaplanacağı belirtilmiştir. Aynı değişiklik kapsamında "gerçek zararın" ne olduğu ve nasıl hesaplanacağı da açıklanmıştır (TBMM 1983). Bahse konu tarihten itibaren orman idaresi, olay mahalline en yakın orman emvali satış istif yerlerinin esas alarak, mevzuata uygun biçimde tazminat cetvelleri hazırlamaktadır. Orman kanununun 112 'inci maddesi B) fıkrası gereğince, fidan kesme suçlarında tazminat miktarı, fidanın tür ve yaşına göre, ekim, dikim ve bakım masraflarının iki katı olarak hesaplanmaktadır.

Devlet ormanlarından ağaç kesilmesi halinde tazminat miktarı, kesilen ağacın hacmi esas alınarak "mahalli rayiç" bedeline göre hesaplanmaktadır. Tazminat miktarı hesaplanmasında, dikiliden kesilmiş ağaçtan elde edilmiş ürünlerin akıbeti her hangi bir şekilde etkili değildir. Ürünlerin kaçırılmış veya sarf edilmiş olması ile tamamına el konulmuş olması arasında bir fark gözetilmemektedir. Hatta ağacın sadece kesilmiş (hayatiyeti sona erdirilmiş) olması tazminat için yeterli olmakta, dalları dahi budanmasa, boylara bölünmemiş olsa da aynı miktarda 
tazminat ödenmesi gerekmektedir. Yasa dışı olarak kestiği ağacı kullanmadan yakalanan kişiler ile elde edilmiş ürünleri sarf etmiş veya kaçırmış olan kişilerin aynı miktarda tazminat ödemeye mahkûm edilmesi eleştirilmektedir. Her iki suçlu arasında tazminat yönünden bir farklılık olması gerektiği belirtilerek hiç olmazsa ürünlerin zapt edilemediği durumda tarife bedeli üzerinden ilave tazminat alınması önerilmektedir (Kayganacıoğlu vd 1976).

Devlete ait ormanlardan kaçak ağaç kesilmesi durumunda tahrip olunan alan için ağaçlandırma bedeli ödenip ödenmeyeceği geçmiş yıllarda tartışılmış olup bu konuda, 1945 yılında, 1945/16 E., 1945/17 tarihli Yargıtay içtihadı Birleştirme Genel Kurulu Kararı bulunmaktadır. Bu kararda, orman suçlarında sebep olunan zararın sanık tarafından karşılanacağı ancak bu kişilerden ayrıca ağaçlandırma bedeli alınamayacağı belirtilmektedir (URL4 2018). 1956 yılından itibaren ise, 6831 sayılı kanun gereğince, ormanlarından ağaç kesilmesi veya her hangi bir şekilde orman diri örtüsünün tahribi halinde ayrıca ağaçlandırma bedeli ödenmesi gerekmektedir. Orman kanununun 114'üncü maddesinde "her türlü orman suçları ile bir dekardan fazla tahrip olunan veya yakılan sahalar için bu kanunda yazılı tazminattan başka ayrıca beher dekar için 200 lira hesabıyla ağaçlandırma masrafına hükmolunur." kuralı getirilmiştir. Bir dekardan daha küçük alanlarda orman örtüsü tahribi halinde ağaçlandırma bedeli ödenmeyecektir. Alan büyüklüğünün bir ölçüt olarak belirtilmesi, orman içinde açılan küçük boşlukların doğal yolla ağaçlarla kaplanabileceği, ağaçlandırmaya gerek duyulmayacağı varsayımına dayandırılmaktadır. Hangi büyüklüğe kadar alanın ağaçlandırmayı gerektirmeden tekrardan orman örtüsü ile kaplanabileceği konusunda teknik bir altlık yoktur. Nitekim 6831 sayılı kanun taslağında ağaçlandırma bedeli istenmesi için açılmış orman alanı büyüklüğünün yarım hektarı (5 dekarı) aşması ön görülmüş olmakla birlikte, TBMM Tarım Komisyonunda büyüklük bir dekar olarak belirlenmiş (TBMM 1956) ve yasa bu şekilde yürürlüğe konulmuştur. Yasaya göre tahrip edilen alanın bir dekarı aşması halinde her bir dekar için 200 TL hesabıyla ağaçlandırma bedeli ödenecektir.
Orman kanununun 114'üncü maddesine göre tahrip olunan orman alanın bir dekarı aşmaması halinde suçlulardan ağaçlandırma bedeli istenmemesini ön gören kanun maddesinin Anayasaya aykırı olduğu iddiası ile 1968/62 Esas sayılı dava açılmıştır. Anayasa Mahkemesi kararında, orman suçu işleyenlerin verdikleri zarardan sorumlu tutulacakları belirtilmiştir. Ancak, küçük alanlardaki orman varlığının yok edilmesi halinde, alanın ağaçlandırılmasına gerek duyulmadan, doğanın kaybı kendiliğinden telafi edebileceği olgusu dikkate alınarak, belli büyüklüğün altında kalan alanlar için ağaçlandırma bedeli alınmaması Anayasaya aykırı görülmemiş ve dava reddedilmiştir. Tahrip olunan orman alanlarının farklı niteliklerde olabileceği ve tamamı için aynı miktarda ağaçlandırma bedeli ödenmesinin de adil olmayacağı iddiaları da dile getirilmiş olmakla birlikte, bu düzenleme de anayasaya aykırı görülmemiştir. Adli yargıda, daha önceden açılmış veya orman içi açıklıklarda işgal ve faydalanmanın sürdürülmesi sonucu yeni orman örtüsü oluşumuna fırsat verilmediği düşüncesi ile bu tür alanlar için de ağaçlandırma bedeli ödenmesi gerektiği yönündeki yaklaşımlar da kabul görmemiştir (Kayganacıoğlu vd 1976).

Bir dekarı aşmayan orman örtüsü tahribatı için ağaçlandırma bedeli alınmaması Anayasaya aykırı bulunmamış olmakla birlikte, bu konudaki tartışmalar sürmüştür. Yaşanan askeri darbe sonrasında, Konsey Hükümeti tarafından 1983 yılında Orman Kanununun 114'üncü maddesi 2896 sayılı kanun ile değiştirilerek, orman suçlarında tahrip olunan alanın büyüklüğüne bakılmaksızın ağaçlandırma bedeli ödenmesi zorunlu kılınmıştır (TBMM 1983). Ayrıca bedel hesabının, tahrip olunan orman alanındaki ağaç cinsine göre cari yıldaki mahalli birim saha ağaçlandırma gideri esas tutularak belirleneceği belirtilmiştir. Böylece, alan büyüklüğüne göre ağaçlandırma bedeli ödenip ödenmemesi ve ödenecek miktarın, oluşan zararı karşılayıp karşılamayacağı konularındaki tartışmalar sonlandırılmıştır.

Hukuki yönden açıklanması gerekli diğer bir husus ise yargılamayı yapan mahkemelerin tazminat ve ağaçlandırma bedeli ödenmesine karar verilmesi için idarenin talebinin gerekli olup olmayacağıdır. Bilindiği 
üzere, 2008 yılı öncesinde, suç nedeni ile oluşan zararın mağdur tarafından ceza davası ile birlikte istenmesi olanaklıydı. Nitekim orman kanununun 112 . ve $113^{\prime}$ üncü maddelerinde "...talep halinde... tazminata hükmolunur" denilmek suretiyle, ceza davasında ancak "istek halinde" tazminata hükmolunacağı belirtilmişti. Diğer yönden, orman idaresinin uğratıldığı zarar için hukuk mahkemelerinde tazminat davası açma hakkı da bulunmaktadır. Ağaçlandırma bedeli için ise; "Her türlü orman suçları ile tahrip olunan veya yakılan sahalar için... ağaçlandırma masrafına da hükmolunur." ifadesine yer verilmişti. Bu maddede "istek halinde" terimi kullanılmadığından, yargılamayı yapan mahkemeler orman idaresinin talebi olup olmadığına bakmaksızın, yasa gereğince ağaçlandırma bedeline hükmetmekteydiler. Nitekim Yargıtay Kararlarında da “...tahrip edilen ormanın tekrar kazanılmasını amaçlayan ağaçlandırma giderine, ileriye yönelik olması ve Yasadan doğan zorunluluk nedeniyle re'sen hükmolunmaktadır." denilmektedir (Mestav 2001).

2008 yılına gelindiğinde, temel ceza kanunlarına uyum sağlamak amacıyla 5728 sayılı kanun ile Orman Kanununda da değişiklikler yapılmıştır. Bu değişiklikler kapsamında, Orman Kanununun 112'inci maddesi değiştirilerek, “... meydana gelen zarar için...hukuk mahkemesinde gerçek zarar üzerinden tazminat talebinde bulunulabilir." ifadesine yer verilmiştir. Yine, Orman Kanununun 114'üncü maddesine de ilave yapılarak, "Bu kanunun 112 ve 113'üncü maddeleri ile bu madde hükümleri uyarınca açılacak tazminata ve ağaçlandırma giderine ilişkin davalar hukuk mahkemesinde görülür." kuralı getirilmiştir. Bununla birlikte, 5271 sayılı ceza muhakemesi kanununun 231'inci maddesine göre, mahkemelerin "hükmün açıklanmasının geri bırakılmasına" karar vermesinde idare zararının giderilmesi gerekli görüldüğünden (RG 2006) ceza davalarında da tazminat ve ağaçlandırma bedelinin tespiti gerekmektedir.

\section{Yürürlükteki Kurallara Göre Orman Suçlarında Tazminat ve Ağaçlandırma Bedel Hesapları}

6831 sayılı orman kanununun 112'inci maddesine göre tazminat hesabı
Orman idaresi, devlet ormanı içinde kalan yerlerde, dikiliden ağaç kesilmesi dışındaki yasa dışı faaliyetlerde bulunanların sebep oldukları idare zararının ödenmesini talep edebilmektedir. Ayrıca, devlet ormanı sınırları içinde veya dışında olduğuna bakıımaksızın, kaçak orman emvali bulduran, taşıyan veya sarf edenlerden de herhangi bir idare zararının tespiti halinde, tazminat talep edebilmektedir. Burada talep edilecek tazminat, uğranılan "gerçek zararın" karşılanmasını sağlayacak kadardır. Orman kanunu gereğince tazimat hesaplamaları, idare tarafından hazırlanan, her yılın mart ayı başından takip eden yılın şubat ayı sonuna kadarki sürede geçerli tazminata esas cetvellere göre yapılacaktır. Hesaplamada, suç tarihi esas alınarak o tarihte geçerli cetvel kullanılacaktır. Tazminatın ödenmesinde, zararın doğduğu an ile ödemenin yapıldığı tarih arasında geçen süre için de idarenin yasal faiz talep etme hakkı vardır.

6831 sayılı Orman Kanununun 112 'inci maddesine göre tazminat talep edilebilmesi için orman suçundan kaynaklanan bir zararın oluşması gerekir. Zapt edilen kaçak orman emvali üzerinde değer kaybettirici herhangi bir işlemin yapılmamış olması halinde tazminat ödenmesi gerekmez. Ancak, ürün değer kaybına uğratılırsa (Örneğin; yapacak vasfındaki emval oduna parçalanırsa) veya kaçak orman emvali sarf edilirse (bir sabit tesiste kullanılırsa) ya da tüketilirse (yakılması vb.) bu hallerde idare zararı karşılanmalıdır. Aksi halde, devlet ormanı içindeki ağaçların meyvelerinin, yapraklarının izinsiz toplanması, mantar vb. ekonomik değeri olan ürünlerin hasadı, alandan taş, toprak vb. maddelerin alınması, düşük veya devrik ağaçların ürünlerinin toplanıp alınması, ağaç̧̧ı veya çalıların kesilip alınması gibi hallerde ürünlerin zapt edilmesi durumunda ayrıca tazminat ödenmesi gerekmeyecektir. Şayet zapt edilmiş orman ürünü üzerinde değer kaybettirici işlemler yapılmış ise bu kez, zapt edilmiş ürünün müdahale edilmeden önceki değeri ile hali hazır değeri arasındaki farkın (idare zararının) tazmin edilmesi gerekir. Konuyu bir örnek yardımı ile açıklamak mümkündür. Dikiliden ağaç kesme dışındaki hallerde, sanık tarafından tomruğun oduna parçalanması ile elde edilmiş kaçak 3 ster yakacak odunun zapt edilmiş olduğu varsayılsın. Bu durumda, bir siter yakacak odunun yaklaşık $0.7 \mathrm{~m}^{3}$ tomruğun oduna yarılması ile elde edilebileceği kabulüyle, zapta konu 
kaçak ürünlerin elde edilmiş olduğu tomruk miktarı $(0,7 \mathrm{X}$ $3=2,1 \mathrm{~m}^{3}$ ) olarak hesaplanıp, orman kanununun $112^{\prime}$ inci maddesine göre hazırlanmış tazminat cetveli kullanılarak, tomruk fiyatından zapt edilmiş odunun değeri çıkarılmak suretiyle idare zararı hesaplanmalıdır.

Yürürlükteki Orman Kanununun 112. maddesine göre tazminat hesaplamalarıyla ilgili örnek alınabilecek çok sayıda Yargıtay kararları vardır. Yargıtay 3. Ceza Dairesinin (C.D.) 20.01.1993, 92/10936-93/979 sayılı kararında, 112 'inci maddenin tatbikinde müsadere edilen emval üzerinde değer kaybettirici işlem yapılmaması halinde tazminata hükmedilmemesi gerektiği açıklanmıştır. Orman ağacı dışında kalan ağaççı ve çalıların kesilmesi halinde de bu bitkilerden elde olunan emvalin zaptı halinde tazminat ödenmesi gerekmeyecektir. Yine; orman ağaçlarının hayatiyetini kaybetmeyecek şekilde budanması halinde de emvalin zaptı halinde tazminat ödenmesi gerekmez. Nitekim Yargitay 3. C.D. 09.09.1997, 97/7726-8862 sayılı kararında, kesilmiş meşe dalları ormana terk edilmişse tazminata gerek olmayacağı belirtilmektedir (Mestav 2001).

Zapt edilmiş orman emvali üzerinde sanık tarafından işlem yapılması (biçerek tahta elde etmek, parke taslağı haline getirmek, kovan yapmak, masa yapmak vb.) tazminat istenip istenmeyeceği değerlendirilirken, ürün üzerinde yapılan işlemin değer kaybına sebep olup olmadığına bakılmalıdır. Eğer işlenmiş ürün standartlara uygun ve değer kaybetmemiş veya daha değerli hale gelmiş ise idareye her hangi bir tazminat ödenmesi gerekmez. Değer artışı sağlandığı için ise sanığa da her hangi bir bedel ödenmez. Örneğin; kaçak ürünlerin daha kolay pazarlanabilecek yerlere taşınması halinde satış fiyatı artsa da sanığa bedel farkı ödenmez. Yine, sanık tarafından standart araçlarla işlenerek mamul hale getirilmesi durumlarında, emval miktarında bir azalma olsa da elde edilmiş mamul ürünler daha yüksek bedelle satılabileceğinden bu durumda idarenin bir zararı olmayacaktır. Bu halde de taraflara her hangi bir tazminat ödenmeyecektir. Bu konuda çok sayıda emsal Yargıtay kararları; Örneğin; Yargıtay 3. C.D. 29.05.1990,T., 13205 E., 6059 K. bulunmaktadır (Özdemir ve Deda 1991). Ancak, zapt edilmiş ürünün sanık tarafından değer kaybına uğratılmasında, Yargıtay 3. C.D. 17.02.1998,
98/32-1432 sayılı kararında açıklandığı üzere, dikiliden kesildiği tespit edilmemiş ağaçtan elde edilmiş yapacak orman emvalinin oduna parçalanmasında tazminatın, odunun yapacak vasıflı değerinden zapt edilmiş yakacak odun değerinin çıkarılması ile hesaplanmalıdır (Mestav 2001).

Kaçak orman emvalinin her hangi bir sabit tesiste (binada, tavan, döşeme, lambri vb. amaçlı sarf edilmesi, tel çit tesisinde kazık vb. amaçla) kullanımı gibi hallerde ürün zapt edilemeyeceğinden bedelinin tazminat olarak istenmesi mümkündür. Bu durumda, sarf edilmiş kaçak orman emvalinin gayri mamul (işlenmeden önceki) miktarı hesaplanarak bu miktar üzerinden suç tarihi itibariyle tazminatı hesaplanmalıdır. Ancak, ürünün devlet ormanı sınırları içinde inşa edilmiş bir sabit tesiste sarf edilmesi durumunda, tesisin tamamının müsaderesine hükmedileceğinden, ayrıca sarf edilmiş ürün için orman idaresine tazminat ödenmesi gerekmez. Bu konuda örnek Yargıtay kararları (Örneğin; Yargıtay 3.CD. 16.06.1998, 98/5920-6894) bulunmaktadır (Mestav 2001).

Orman alanı içindeki fidanların hayatiyetine son verecek eylemlerde bulunulması halinde verilen zararın iki bir misli fazlası tazmin edilecektir. Orman kanununun 112 'inci maddesi b) bendine göre tazminat, fidanların her birisinin dikimi ve arazi hazırlanması için hesaplanacak gerçek masraflar ile o yıla kadar hayatiyetine son verilmiş fidanlar için yapılmış bakım giderleri toplamı bir misli fazlasıyla tazmin ettirilecektir. Bu kural ölü fidanlar için işletilmeyecektir.

Orman yangınları nedeniyle oluşan zararın nasıl hesaplanacağı konusunda ise tarihsel süreç içinde farklılıklar bulunmaktadır. Orman yangınlarında meydana gelen zararın tespitinde 1959 yılına kadar sadece yanan ağaçların tarife bedeli kadar tazminat talep edilmiştir (Ünal 1991). Tarihi sürecin açıklandığı kısımda belirtildiği üzere, kasten veya tedbirsizlik sonucu orman yakma suçlarında tazminatın Borçlar Kanunu hükümlerine göre hesaplanması yoluna gidilmiştir. 1983 yılından itibaren ise orman kanununun 12 'inci maddesi gereğince, yanan veya yangından zarar gören her çeşit orman örtüsü için oluşan değer kaybı dikkate alınarak "gerçek zarar" üzerinden tazminat hesapları yapılmaktadır. Bu hesaplamaya, ağaç, 
ağaç̧ık veya çalı türünden olup ta ekonomik değeri hesaplanabilen her çağdaki (fidan çağı, ince ağaçlık çağı vb.) tüm bitki örtüsü dahildir. Orman kanunu gereğince, ağaç kesme suçlarından farklı olarak, yangın nedeniyle ölen orman ağaçları için, ağacın yangın öncesi ve sonrası odun değeri tespit edilerek (yangın nedeniyle oluşan değer kaybı hesaplanarak) aradaki değer azalmasının tazmini gerekir.

6831 sayılı orman kanununun 113'üncü maddesine göre tazminat hesabı

Ormancılıkla ilgili mevzuatta evvelinden beri orman suçlarında uğranılan zarar için ayrım gözetmeksizin tazminat talep edilmekte iken, 1956 tarih ve 6831 sayılı orman kanununun kabulü ile birlikte, devlet ormanlarından dikiliden ağaç kesilmesi suçları için farklıık arz eden tazminat talebi yoluna gidilmiştir. Bu tür eylemlerde tazminat "rayiç bedel" üzerinden hesaplanacaktır. Önceden hazırlanmış tazminat cetvelleri kullanılarak ağaç türü, vasfı ve miktarı esas alınarak tazminat hesabı yapılmaktadır. Tazminat hesabında, kaçak olarak kesilen ağaçtan elde edilmiş ürünlerin akıbeti dikkate alınmamaktadır. Zira, kanunda, “... ağaç müsadere edilmiş olsa dahi hükmolunacak tazminat mahalli rayiçe göre hesaplanır" denilmektedir. Orman kanununda, kaçak olarak kesilmiş ağacın hacminin nasıl hesaplanacağı konusunda ise açıklama yoktur.

Periyodik olarak yenilenen orman amenajman planlarında, düzenlenmiş hacim tabloları da kullanılarak, çalışma alanı (plan ünitesi) içindeki ağaçların çap sınıflarına göre kabuklu dikili gövde hacimleri (KDGH) hesaplanmakta ve bu sonuçlar ilgili planlarda tablolar halinde sunulmaktadır. Plan uygulayıcıları tarafından işlem yapacakları ağaçların göğüs hizasındaki çaplarını ölçüp, hazırlanmış tabloları da kullanarak ağaçların KDGH hesaplanmaktadır. Uygulamada, kaçak olarak kesilmiş ve kaçırıımış ağaçların göğüs çapının hesaplanmasında, 1982 yılına kadar, aynı ağaç türünde dip kütük kalınlığı eşit olan emsal ağacın hacmi esas alınarak hesap yapılmaktaydı. Ormancılık Araştırma Müdürlüğü tarafından yapılan araştırma (Giray N 1982) neticesinde, orman ağaçlarının dip kütük kalınlıkları ölçülerek göğüs yüksekliğindeki (yerden 1,3 metre yükseklikte) çaplarının ve ağacın orta çapının hesaplanacağı formül üretilmiştir. Buna göre, ağacın dip kütük çapı 0,8 ile çarpılarak göğüz çapı, yine dip kütük çapı 0,5 ile çarpılması suretiyle de orta çapının bulunacağı kabul edilmiştir. Belirtilen tarihten itibaren kaçak olarak kesilerek kaçırılmış ağaçlar için hacim hesaplamasında bu değerler kullanılmaktadır. Dip çap ile göğüs çapı arasındaki ilişki, ağaç türüne, gelişim çağına hatta yetişme ortamına göre farklılık gösterebilir. Nitekim ülkemizde, farklı ağaç türleri için dip kütük çapı ile göğüs çapı arasındaki ilişkiyi ortaya koyan birçok model çalışma yapılmıştır (Uğurlu ve Özer 1977, Giray 1982, Yavuz 1996 ve 2000, Özçelik 2005, Şenyurt 2012). Daha hassas tazminat hesabı yapılması için bu araştırma sonuçlarından da yararlanılabilir.

Orman kanununun 113'üncü maddesine göre yapılan tazminat hesaplamalarında, öncelikle kaçak olarak kesilmiş ağacın vasfı (yapacak ürün veya yakacak ürün elde edilebilir olduğu) tespit edilmektedir. Sonrasında, yerleşik Yargıtay kararları dikkate alınarak, ağacın göğüs çapına göre göre KDGH hesaplanmaktadır. Yargıtay kararlarında, orman ürünlerinin hacim hesabında "orta kuturun" esas alınacağı belirtildiğinden, her ne kadar dikili ağacın hacmi göğüs yüksekliğindeki çapı esas alınarak amenajman planı verilerine göre tespit edilse de raporlarda hacimlendirmenin "orta kutura" göre yapıldığı yazılarak tereddüt oluşması önlenmektedir. Ayrıca, yine yerleşik Yargıtay kararları (örneğin; Yargıtay 3.CD. 14.02.1989 T. $1989 / 1055$ E, 1989/1157 K. ve Yargitay 3.CD. 10.02.1999 T. 1998/13576 E, 1999/908 K.) dikkate alınarak, yapacak ürün elde edilebilecek ağaçlar için tazminat talebinde kaçak olarak kesilmiş ağacın sadece KDGH esas alınmakta, ağacın dal ve diğer yakacak kısımları için ayrıca tazminata hükmedilmemektedir (Kızılay 1991).

\section{Orman Suçlarında Ağaçlandırma Bedeli Hesabı}

Güncel mevzuata göre yasaya aykırı olarak devlet ormanlarında örtü tahribat yapılması halinde cezalandırmanın yanı sıra sanıkların ağaçlandırma bedeli de ödemeleri gerekmektedir. Ağaçlandırma bedeli ödenmesi için eylemle "diri" orman örtüsünü tahrip edilmiş olmalıdır. Ancak, yargı kararlarında dikili kuru haldeki orman ağaçlarının kesilmesi durumunda da ağaçlandırma bedeli ödenmesi gerektiği belirtilmektedir. Burada, ağaç ölü olsa da toprağı siperlediği ve erozyona 
karşı koruduğu değerlendirilmektedir. Diğer bitki örtüsü için ise "diri olma" koşulu aranmaktadır. Diri orman örtüsü, ağaç, ağaç̧̧ık, çalı vb. her çeşit canlı bitkileri kapsamaktadır. Ancak, yerleşik içtihat kararlarında orman alanı içindeki ağaçların hayatını sonlandırmayacak biçimde yaralanmaları veya sadece dallarının kesilmesi durumlarında ağaçlandırma bedeli ödenmesi gerekmemektedir. Bununla birlikte, ağacın kökünden kesilmesi halinde, dip kütüğün canlı olması, sürgün vermesi hallerinde dahi (Yargitay 3.CD. 2001/10941 E., $1055 \mathrm{E}, 2001 / 19001 \mathrm{~K}$.) ağaçlandırma bedeli ödenmesi gerekir. Ağaçlandırma bedeli ödenmesi konusunda, Yargıtay 3. C.D. yerleşik içtihatlarıyla çelişen hukuk dairesi kararlarına da rastlanmaktadır. Nitekim, Yargıtay 3. Hukuk Dairesinin 2005/11636 E., 2005/12534 Esas sayılı Kararında, "Tahribatın varlığını kabul edebilmek için ağaçların mutlaka hayatiyetini kaybetmesi gerekmez. Orman örtüsünün kaldırılması suretiyle ağaç yetişmesi engellendiği gibi, tepe sürgünleri ve yan dalların yenilmesi ağaçların gelişimini engelleyeceğinden farazi olarak ağaçlandırma masrafına hükmedilebilir." denilerek kapsam geniş tutulmaktadır (URL-5 2018).

Orman suçlarında, tahrip edilen orman diri örtüsünün kapladığı alan esas alınarak hakim ağaç türü esas alınarak ağaçlandırma bedel hesabı yapılacaktır. Ağaçlandırma bedel hesaplarında, her bir ağaç türü için hazırlanmış cetvellerdeki değerler kullanılmaktadır. Orman idaresi lehine ağaçlandırma bedeline hükmedilmesi için, tahrip olunan orman alanı üzerinde ağaçlandırma faaliyetinde bulunulması/bulunulacak olması koşulu aranmamaktadır. Burada, diri orman örtüsünün tahrip edilip edilmediği esas alınmaktadır. Ancak, orman örtüsünün tahribinden itibaren 8 yıl veya daha fazla süre geçmiş olması durumunda açma suçu zamanaşımına uğradığından bu durumda sanıktan ağaçlandırma bedeli de talep edilemeyecektir. Yine, orman örtüsü tahribinden itibaren 8 yılı aşkın süre geçmesi durumunda, alanın halen kullanılmakta olması halinde de idareye ağaçlandırma bedeli ödenmeyecektir. Zira, orman örtüsü tahribatı suçu zamanaşımına uğramış olup alanın kullanılmaya devam edilmesi işgal ve faydalanma suçunu oluşturmaktadır. Yargı kararlarında da bu durum açıklanmakta (Örnek; Yargıtay 3.CD. 03.02.1997, 97/129-1115) ağaçlandırma bedeli ödenmesinin, orman örtüsü tahrip edildiği tarihten itibaren ceza zamanaşımı süresi ile sınırlı olduğu belirtilmektedir. Arazinin kullanılmaya devam edilmesi sebebiyle alanda orman örtüsünün oluşmasına engel olunduğu gerekçesi ile ağaçlandırma bedeli ödenmesi görüşü ise yargı tarafından kabul görmemiştir.

Ormanların tahribine sebep olan en önemli etkenlerden birisi de orman yangınlarıdır. Bu yangınlar için tazminattan başka, katlanılan yangın söndürme giderlerinin ve tahrip olan orman alanının ağaçlandırma bedelinin ödenmesi gerekir. Orman yangınının örtü yangını (Orman toprağını örten -ot, çayır, funda, fide, fidan, yaprak, yosun, humus, kuru dal, kütük, devrik kesim artıkları v.s. ölü ve diri örtüyü yakan, orman ağaçlarının yanmadığı yangındır.) şeklinde seyretmesi ve sönmesi/söndürülmesi hallerinde ağaçlandırma bedeli ödenip ödenmemesi konusunda çelişki vardır. Orman Genel Müdürlüğü tarafından hazırlanmış 285 sayılı Orman Yangınlarının Önlenmesi ve Söndürülmesinde Uygulama Esasları Tebliği'nin "Yangın Hasarat Raporlarının Düzenlenmesinde Dikkat Edilecek Hususlar" başlığı altında "Yanan orman sahası ile 114'üncü maddeye göre tespit edilen ağaçlandırma fiyatı çarpılarak bulunan değer ağaçlandırma masrafıdır. Yangının örtü yangını şeklinde devam etmiş ve sahada yangın neticesi diri örtü hariç asli ağaç türlerinde bir zarar meydana gelmemişse ağaçlandırma masrafı hesaplanmayacaktır. Ancak yer yer kurumalar olduysa kuruma olan alanlar için ağaçlandırma masrafı hesaplanacaktır." şeklinde açıklama yapılmıştır (OGM 1995). Ancak, bu Tebliğ'in yayınından kısa süre sonra, maddi hata yapıldığı belirtilerek örtü yangını olan sahalar için de ağaçlandırma bedeli istenmesi talimatı verilmiştir. Bu kapsamda, örtü yangına maruz kalmış ve orman ağaçlarının, ağaççıklarının her hangi bir zarara uğramamış olduğu hallerde de ağaçlandırma bedeli talep edilmektedir.

\section{TARTIŞMA VE SONUÇ}

Orman suçu işlenmesi nedeniyle oluşan zararların hesaplanması oldukça zordur. Zira yasaya aykırı olarak kesilen her ağaç veya tahrip edilen her orman alanı, doğa üzerinde önemli değişikliklere, bozulmalara neden olmakta, ormanların sürdürülebilirliğini baltalamaktadır. Meydana gelen zararın objektif kriterlere dayalı olarak 
hesaplanması da çoğu zaman mümkün olamamakla birlikte, orman kanunlarında zararın hesaplanması yol ve yöntemleri konusunda düzenlemelere yer verilmiştir. Orman kanunlarının tazminata ilişkin düzenlemeler bazen genel hukuk kuralları ile de farklılıklar içermekte, bazen de hakkaniyete uygunluk konusunda tartışmalara sebep olmaktadır.

Ormancılık mevzuatında tazminat ve ağaçlandırma bedelleri çoğunlukla orman kanununun 112, 113 ve 114'üncü maddelerine göre hesaplanmaktadır. Kanunun 112'inci maddesi "gerçek zarar" miktarının hesaplanmasını ve sanıktan istenilmesini içermekte olup bu yöntem esas itibariyle genel hukuk kurallarına uygun görülmektedir. Ancak, 1983 yılında 2896 sayılı kanun ile orman kanununda yapılan değişiklik sonrasında, bahse konu maddenin " $B$ " $f$ ıkrası, fiilin konusunun fidan olması durumunda, kurum harcamalarının bir misli fazlasıyla tazmini ön görülmektedir. 1980 yılındaki askeri darbe sonrası Konsey Hükümeti döneminde yapılan bu değişikliğin nedeni anlaşılamamıştır. Değişikliğin yapıldığı tarihteki Milli Güvenli Konseyi Tutanaklar Dergisi incelenmiş olup, görüşmeler sırasında da değişiklik üzerinde her hangi bir değerlendirme yapılmadığı tespit edilmiştir (TBMM 1983). Fidan kesme suçu zaten diğer ağaç kesme suçlarına göre daha ağır ceza uygulanan bir eylemdir. Tazminat ise ceza olmayıp verilen zararın karşılanmasından ibaret olmalı, sebepsiz zenginleşmeye neden olmamalıdır.

Orman kanununun 113'üncü maddesinde, dikiliden ağaç kesme suçlarında ürünün akıbetine bakılmaksızın (zapt edilmiş olması/olmaması, tüketilmesi, vasfının değiştirilmiş olması vb.) idarenin isteği halinde tazminat bedeli ödenmesi ön görülmektedir. Fidanlık çağını aşmış ağaçlar için, Yargıtay kararlarında da kabul gördüğü üzere KDGH esas alınarak hacim hesabı yapılmaktadır. Yapacak vasıfta ağaçların yakacak olarak kullanılabilecek kısımlar (dal, vasfı bozuk gövde kısmı, uç kısımlar vb.) tazminat hesabına dahil edilmemektedir.

Haksız fiil nedeniyle tazminat taleplerinde ilk adım zararın doğru hesaplanmasıdır. Güncel mevzuatta ve yargı tarafından genel kabul gören uygulamalarda zarar hesaplamaları hatalıdır. Öncelikle tazminata konu kaçak olarak kesilmiş ağacın üretime konu edilmesi halinde hangi vasıfta ve ne kadar ürün elde edilebileceğine bakılmaksızın KDGH esas alınarak tazminat istenmesi hayatın gerçeği ile bağdaşmaz. Zira hiçbir ağacın tüm ürünü tomruk veya maden direk vasfında olamaz. Üretime konu edilen ağaçtan, kalınlığı ve gövde yapısına göre farklı niteliklerde yapacak ve yakacak odun elde edilir. Nitekim orman idaresi tarafından yapılan dikili satışlarda, satışa konu ağaçlardan elde edilecek ürünlerin miktar ve niteliği tespit edilerek ona göre fiyat hesaplaması yapılmaktadır. Orman suçlarında kesilen ağaçlar için de aynı yöntem kullanılarak ürün tespiti ve ona göre tazminat hesabı yapılması gerekir.

Tartışılması gereken diğer bir konu da kaçak olarak kesilmiş ağaçtan elde edilmiş ürünlerin zapt edilip edilmediğine, değer kaybına uğratılıp uğratılmadığına bakılmaksızın sanıklardan aynı tazminatın isteniyor olmasıdır. Nitekim bu uygulama Kayganacıoğlu ve arkadaşları tarafından eleştirilmiş olup, ürünü kullanan ve kaçıranların diğerlerine göre tazminat yönünden daha elverişli hale geldiği belirtilmiştir. Bir görüş olarak, güncel mevzuata uygun olmamakla birlikte, kaçak kestiğ ağaçtan elde edilen ürünleri kaçırmış olanların hiç olmazsa tazminatın yanı sıra tarife bedeli de ödemeye mahkum edilmeleri önerilmektedir (Kayganacıoğlu vd 1976). Bu görüşe katılmak mümkün değildir. Çünkü burada suç nedeni ile sebep olunan zararın hakkaniyete uygun hesaplanması değil, sanıklar arasındaki eşitsizliğin ortadan kaldırılması düşünülmektedir.

Tazminat hesaplanmasında diğer bir eşitsizlik ise ağaç kesme suçları ile yangın sonucu ölen ağaçlar için yapılacak bedel hesaplarının uyumsuzluğudur. Daha önce açıklandığı üzere, kesme, boğma vb. yolla ağacın hayatiyetini sonlandırmada, öldürülen ağacın KDGH esas alınarak tazminat hesaplanmaktadır. Yangınlarda ise, yanarak ölen ağaçlar için, yangın öncesi ürün değeri ile yangın sonraki hesaplanan değer arasındaki eksilme, yani "gerçek zarar" hesaplanmakta ve tazminat olarak istenmektedir. Suç nevi farklı olsa da her iki halde de dikili orman ağacı ölmektedir. Ceza yönünden farklılık olması beklenen bir durum olmakla birlikte, tazminat yönünden farklılığın bilimsel açıklamasının bulunmadığ düşünülmektedir. 
Devlet ormanından kaçak ağaç kesme suçlarında "gerçek zarar" miktarını aşan tazminat istenmesi Kayganacıoğlu ve arkadaşları tarafından, "dikili ağacı kesmenin tehlikesinin ağırlığı hesaba katılması" olarak değerlendirilmektedir. Yargıtay kararlarında da devlet ormanından ağaç kesmenin, orman varlığı ve sürekliliğini tehdit ettiği için daha ağır tazminata konu edilmesinin olağan karşılanması yönünde çok sayıda değerlendirmeler vardır. Bu yaklaşım ceza yönünden doğrudur. Nitekim orman kanununda, devlet ormanından kaçak ağaç kesme suçları için diğer suçlardan farklı hapis ve adli para cezası öngörülmüştür. Ancak, tazminat ile ceza birbirinden ayrılmalıdır. Diğer yönden, kasıtlı olarak orman yakma veya kusurlu davranarak orman yangınlarına sebep olma suçlarında idare zararı "gerçek zarar" esas alınarak hesaplanmaktadır. Devlet ormanından kaçak ağaç kesme suçlarının orman yakma suçlarına göre orman varlığı ve sürekliliği bakımından daha ağır tehdit oluşturduğu söylenemez. Bu durumda, eylemin sebep olduğu zarardan daha fazlası tazminat olarak talep edilmemelidir.

Orman suçlarıyla diri orman örtüsünün tahribi halinde verilmiş zararın tazmininin yanı sıra ağaçlandırma bedeli de ödenmesi gerekir. Bu konuda açıklığa kavuşturulması gerekli hususlar vardır. Bunlardan birisi, orman içinde veya kenarındaki boşluklarda otsu bitkilerin kapladığı alanlara zarar verilmesi halinde ağaçlandırma bedeli ödenip ödenmeyeceğidir. Kanaatimizce, otsu bitkilerin köklerine zarar verilmeden biçilmesi veya her hangi biçimde yok edilmesi ağaçlandırma bedeli ödenmesini gerektirmez. Bu tür alanların kazılarak veya üzerine malzeme yığılarak tahribi halinde de yok edilen her hangi bir odunsu bitki olmadığından ağaçlandırma bedeli istenmemelidir. Ancak, mera alanlarındaki yaptırımlara benzer biçimde ot bedeli ve eski haline getirme bedeli istenilebilir.

Devlet ormanından büyüklüğü ölçülebilen diri örtü tahribatında açılan orman alanının tamamı esas alınarak ağaçlandırma bedeli hesaplanmaktadır. Ancak, orman alanı içinden münferit halde ağaç kesiminin olduğu hallerde ağaçlandırma bedel hesabı konusunda sorun vardır. Şöyle ki; çoğu zaman, suça konu meşçere tipinde hektardaki ağaç âdeti esas alınarak hesaplama yapılmaktadır. Örneğin, \% 25 kapalı bir meşçerede bir hektarlık alanda 50 adet ağaç bulunsun. Bu durumda kaçak olarak kesilmiş her bir ağaç için (10 000/50) 200 m2 orman alanının açıldığı kabul edilmekte ve her bir kaçak kesilmiş ağaç için $200 \mathrm{~m} 2$ alan esas alınarak ağaçlandırma bedeli istenmektedir. Hâlbuki orman boşluklu kapalııkta olup kaçak kesilmiş her bir ağacın tepe tacı hesaplanmış 200 m2'den daha az araziyi siperlemektedir. Bu meşçere tipinde mevcut ağaçların tepe taçlarının örtmediği yaklaşık \% 75 alan vardır.

Orman alanı içinden münferit halde ağaç kesme suçlarında, kaçak olarak kesilmiş ağaçların, çap, tür ve meşçere sıklı̆ına göre tepe taçları (çevredeki emsal ağaçlar, diri örtü vb. bulgular yardımıyla) belirlenmeli ve bu tespite göre tahrip edilmiş orman alanı hesaplanmalıdır. Böyle bir gözlem mümkün olmazsa, amenajman planındaki meşçerenin kapalılık durumu da dikkate alınarak hesaplama yapılmalıdır. Örneğin; "LKncd1" (orta ve kalın ağaçlık çağında toprağı \% 11 ila 40 arasında siperleyen), amenajman planı 13 numaralı tabloya göre toplam 50 adet orman ağacı bulunan bir meşçereden münferit halde 3 adet ağacın kaçak olarak kesilmiş olduğunu var sayalım. Bu durumda, kapalııı̆ın \% 25 olduğunu kabul ederek, ağaçlandırma bedeline esas olacak orman alanı büyüklüğü $X=(10000 \times 0,25) / 50 \times 3$ $=150 \mathrm{~m} 2$ olarak hesaplanacaktır. Orman alanında ağaçların yanı sıra ağaççık ve çalı türünde odunsu bitkilerinde tahribi halinde açılmış tüm alana göre ağaçlandırma bedeli istenmelidir.

Yangın suçlarında tahrip olan ağaç ve ağaççıklarla kaplı yerler için ağaçlandırma bedeli ödenecektir. Ancak, örtü yangınlarında, orman ağaçlarının ve diğer odunsu bitkilerin her hangi bir zarara uğramadan hayatiyetini sürdürmeleri halinde ağaçlandırma bedeli istenmemelidir. Şayet, örtü yangınında, alevler alanı adeta yalayarak geçmiş, sadece kuru otlar ve son yıllarda dökülmüş olan yapraklar yanmış, toprakta zarar oluşmamış, toprağın üzerindeki nemli humus tabakası dahi varlığını sürdürmekte ise ağaçlandırma bedeli istenmesi hakkaniyete uygun olmayacaktır. Özellikle Doğu Karadeniz Bölgesinde vejetasyon mevsimi dışında bu tür yangınlara rastlanmaktadır. Bu hallerde, sahanın her hangi bir şekilde çıplak kalarak erozyona uğraması 
veya yeniden ağaçlandırması gerekmemektedir. Alan üzerindeki odunsu bitkiler hayatını sürdürmekte, otsu bitkilerin kökleri de ölmediğinden toprağı korumaya devam etmektedirler. Yangın suçlarında oluşan zararın miktarı ve ağaçlandırmanın gerekli olup olmadığı, ne kadar alanda ağaçlandırma yapılması gerektiği konularında idarenin kapsamlı bir çalışma yapması, uyuşmazlığın çözümünde görev yapacak orman mühendisi bilirkişilerin de bu konuyu anlayacak ve açıklayacak donamımda olması önem arz etmektedir.

Oluşan zararın tazminat cetvellerinde yeterince yansıtılamadığı, mesela orman örtüsünün tahrip edildiği suçlarda sadece ağaçların ölmediği, ağaç̧̧ık, çalı, mikro organizmalar, hayvanlar, tohumlar, otsu bitkiler vb. birçok canlının zarar gördüğü, yok edildiği, toprağın yapısında bozulmalar olduğu, bağlı karbonun atmosfere salınmasına sebep olunduğu gibi dış dünya üzerinde meydana gelen zararlardan bahsedilebilir. Yine, tahrip edilen orman alanında biyolojik çeşitliliğin zarar görmesine, endemik bitkiler, tıbbi değeri olan canlı veya cansız varlıkların yok olması gibi olumsuzluklara sebep olunabilir. Ayrıca, kaçak olarak kesilen ağaçların, büyüme ve gelişmesinin önlendiği, toprağı koruma, iklimi yumuşatma, karbon bağlama, havayı filtre etme vb. birçok faydasının sonlandırıldığından bahisle, suçluların sebep oldukları zararın talep edilen tazminattan çok daha fazla olduğu da öne sürülebilir. Yapılması gereken; yasa dışı eylemler sonucunda ekosistemde oluşan zararın bilimsel araştırmalara dayalı olarak ortaya konulmasıdır. Bunun için, farklı disiplinlerde uzmanlığı olan ilgililerin bir proje bazında ortak çalışması gerekli görülmektedir. Böylece, orman suçları sonucu ortaya çıkan gerçek zarar tespit edilip sebep olanların zararı karşılamaları sağlanabilir.

\section{KAYNAKLAR}

Aksoy M (1987) Anayasalarımız ve Ormanların Korunması. Cumhuriyet Dönemi Ormancılığımızda 3116 Sayılı Orman Yasası ve Sonrası Sempozyumu Türkiye Ormancılar Derneği Yayınları No: 10, Ankara.
Bingöl İH (1990) Geçmişten-Günümüze Ormanlarımız ve Ormancılığımız. Ormancılık Eğitim Vakfı Yayın No: 4 Matbaa Teknisyenleri Basımevi Cilt I, XI+157+144 Ek, İstanbul.

Diker M (1947) Türkiye'de Ormancılık Dün-Bugün-Yarın. T.C. Tarım Bakanlığı OGM Yayınlarından, Sayı: 61 Akın Matbaası VI+132, Ankara.

Giray N (1982) Ağaçlarda kütük çapı, orta çap, göğüs çapı ilişkisi. O.A.E. Dergisi Temmuz Sayısı Cilt:28: 69-79.

Gülen I, Özdönmez M (1981) Türkiye'de Orman ve Ormancilık. İstanbul Üniversitesi Orman Fakültesi Dergisi Seri: B Cilt: 31 Sayı: 2, İstanbul.

Gümüş C (2004) Ormancılık Politikası. Cilt: 1 Karadeniz Teknik Üniversitesi Orman Fakültesi Genel Yayın No:216 Fakülte Yayın No.: 34 Karadeniz Teknik Üniversitesi Matbaası, Trabzon

Kayganacıoğlu MR, Renda N, Onursan G (1976) Gerekçeli-Açıklamalı-içtihatı Orman Kanunu ilgili Mevzuat. Olgaç Matbaası XXXI+1195, Ankara.

Kızılay E (1991) 6831 Sayılı Orman Kanunu ve Orman Suçlarının Takibi. Orman Genel Müdürlüğü Yayını, Ankara.

Mestav M (2001) Açıklamalı-içtihatlı Orman Kanunu ve İlgili Mevzuat. ISBN 975-97564-0-4 Yayın Matbaacılık ve Ticaret İsletmesi XVI+1280, Ankara.

OGM (Orman Genel Müdürlüğü) (1995). Orman Yangınlarının Önlenmesi ve Söndürülmesinde Uygulama Esasları OGM yayınları, Ankara.

OGM (Orman Genel Müdürlüğü) (2016) Orman Genel Müdürlüğü Stratejik Plan 2017-2021.

Özçelik R (2005) MUT orman işletmesinde karaçam, sedir ve kızılçam ağaç türleri için dip çap-göğüs çapı ilişkisi. S.D.Ü.Orman Fakültesi Dergisi 9:3

Özdemir Ş, Deda N (1991) Orman Hukuku, Hukuk, Ceza ve Kadastro Davaları. Cilt:Il Feryal Matbaacılık san. İç ve Ltd. Şti, Ankara.

Resmi Gazete (2006) Çeşitli Kanunlarda Değişiklik Yapılmasına ilişkin Kanun. Sayı:26381 Tarih: 06.12.2006.

Şenyurt M (2012) Batı Karadeniz Yöresi Sarıçam (Pinus sylvestris L.) Meşcerelerinde Kütük Çapı-Göğüs Çapı İlişkileri. Artvin Çoruh Üniversitesi Orman Fakültesi Dergisi 13(1):79-87.

TBMM (1956) Devre: X İçtiam:2 Sıra sayısı: 298 Orman Kanunu Layihası ve Ziraat ve Muvakkat encümenleri mazbataları (1/181), 24.01.1955.

TBMM (1983) Tutanaklar Dergisi Cilt 10 165. Birleşim Sayfa: 135, Ankara.

Uğurlu S, Özer E (1977) Kızılçamlarda kütük çapından yararlanarak göğüs çapının bulunması. O.A.E. Dergisi Ankara Cilt No:23 Sayı:1:71-77.

URL-1 http://www.fao.org/news/story/pt/item/40893/icode/. Erişim: 06.02.2018.

URL-2

http://www.ogm.gov.tr/ekutuphane/Yayınlar/T\%C3\%BCrkiye\%200rman \%20Varl\%C4\%B1\% C4\%9F\%C4\%B1-2016-2017.pdf. Erişim: 07.02.2018.

URL-3 http://www.sozlukanlamine.com/cibali-mubaha-132739 Erişim=08.02.2018.

URL-4 (http://www.hukuki.net/ictihat/2390-2403.asp).

URL-5 http://www.bakale.com/icgoster.php?kat=3\&icno=504

Ünal S (1991) Orman Yangınlarından Doğan Zarar Düzeyinin Hesaplanması Üzerine Araştırmalar. İstanbul Üniversitesi Orman Fakültesi Dergisi Seri: A Cilt: 41 Sayı: 1 İstanbul.

Yavuz H (1996) Taşköprü orman işletmesinde sarıçam ve karaçam ağaç türlerimize ilişkin dip çap-göğüs çapı orta çap ilişkileri ile kabuk hacminin hesaplanması. K.T.Ü Orman Fakültesi Bahar Yarı Yılı Seminerleri Seminer No:2:67-75.

Yavuz H (2000) Dişbudak ağaç türü için dip kütük çapı ile göğüs çapı arasındaki ilişkinin belirlenmesi. K.T.Ü Orman Fakültesi Güz Yarı Yılı Seminerleri Seminer No:7: 10 